\title{
Relationship of Prayer With Mental Health
}

\author{
${ }^{1}$ Dadang Herdiansyah, ${ }^{2}$ Sri Ramadhan, ${ }^{3}$ Muhammad Farid, ${ }^{4}$ Andriyani Asmuni, ${ }^{5}$ Masyitoh, \\ ${ }^{6}$ Ernyasih, ${ }^{7}$ Abul A'la Al Maududi, ${ }^{8}$ Dihartawan \\ ${ }^{1-8}$ Faculty of Public Health, Muhammadiyah University of Jakarta \\ K.H. Ahmad Dahlan Street, Cireundeu, Ciputat, South Jakarta, 15419 \\ E-mail: sriramadhan29@gmail.com
}

\begin{abstract}
The increase in the population in Indonesia experiencing mental disorders is getting sharper. In Islam, more worship will promote good mental health. This research uses library research methods. Based on the results of literature research shows that someone who always performs prayer can overcome the problems of life that are being experienced so tends to have good mental health. The implementation of worship in the context of Islam such as the implementation of prayers, remembrance, reading the Qur'an, and other worship, can be a way to get mental health.
\end{abstract}

Keywords: Mental health, prayer, worship 
Volume I Tahun 2021

November 2021
E-ISSN: 2808-5361

http://e-journal.fkmumj.ac.id/
Proceeding The First Muhammadiyah InternasionalPublic Health and Medicine

Conference

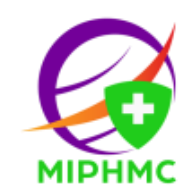

\section{INTRODUCTION}

According to Reza (in Lubis et al., 2019), If children and adolescents can display behavioral habits that are following norms, values, and rules that exist in society, the teenager can be said to obey and have good moral standards. Meanwhile, adolescents who exhibit behavior that is contrary to the norms, rules, and values that apply in society then adolescents can be said to commit immoral acts.

Research conducted by (Indonesian Ministry of Health, 2018) shows that 9-10 out of 100 Indonesian occupation people experience mental disorders. That's a sharp increase from data in 2013 that showed a figure of $6 \%$.

Among the Islamic community, they always routinely perform obligatory prayers and sunnah to improve the quality of piety and to overcome life problems. By always heeding to Allah SWT, which gives rise to a sense of calm and peace in the soul. This is a therapy of anxiety that humans feel when he gets themselves weak in the face of life's problems.

According to the book Thibbun Nabawiyy, Ibn Qayyim al Jauziyyah (in Ma'rufah, 2015)said, "prayer brings windfalls, maintains health, rejects distractions, expels disease, rejects laziness, activates members, helps strength, stretches the chest, gives food to the spirit, illuminates the heart, preserves favors, rejects disasters, brings blessings, draws away demons and draws near to God the Most Merciful"

From the description above it can be concluded that prayer in its sense is widely influencing mental health. Seeing the importance of prayer in the formation of positive human character directs his life goals for the realization of a healthy mind so that one can play an optimal role in achieving birth and inner happiness.

\section{METHODS}

This article in the study uses library research methods or Library Research, which is a series of activity steps related to library data collection methods.

Meanwhile, the object of research in this scientific article is about the relationship of prayer to mental health. The research object in this article lays out the results of research and literature studies on the effects and benefits of prayer to developmental health. Several other research journals are reference researchers to uncover the object of research in this article.

\section{RESULTS AND DISCUSSIONS}

The results of research from (Firdaus, 2016) Islam has its own and distinctive concept about mental health. The Islamic view of mental health is based on religious principles and falsafat thoughts contained in Islamic teachings. It can be asserted that faith and piety have very close relevance to the 
E-ISSN: 2808-5361

http://e-journal.fkmumj.ac.id/
Proceeding The First Muhammadiyah InternasionalPublic Health and Medicine Conference

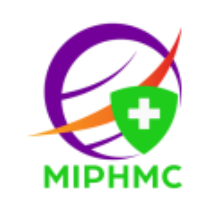

question of psychiatry. Faith and piety are the true meaning of psychology and mental health for humans in Islam. Only to Allah, Allah will give their hearts a sense of security, calm, and peace so that they can move to the maximum to achieve the desired results.

From the results of the study, it can be said that good mental health has a close relationship with faith and piety. Because the greater our faith and piety in God will give us a sense of comfort.

Based on this research study (Reza, 2015) proves that individuals who understand and live the implementation of worship, able to overcome life problems that are being experienced, so tend to have good mental health. The implementation of worship in the context of Islam such as the implementation of prayers, remembrance, reading the Qur'an, and other worship, can be a way to get mental health.

The perception and deepening of religious science can overcome life problems to prevent the occurrence of bad mental health.

Based on the results of the literature research studying this article shows (Lubis et al., 2019) The implementation of worship in Islamic contexts such as the implementation of remembrance, reading the Qur'an, especially prayer becomes a way to achieve good mental and physical health in adolescents to develop great youth potential as a generation of nations in developing regional potential towards a superior and better Indonesia.

In these results to achieve good mental health, the implementation of worship such as prayer is very influential in developing potential.

The results of research from (Suparman, 2015) Apabila prayer done correctly and full tokhusyu'an, will be a means of health and psychological development that is difficult to find in other worships.

Prayer is very influential on mental health if done correctly because in specialty then we will get peace of mind in performing prayers.

From research conducted by (Ma'rufah, 2015) shows that in prayer, the servant seems to be before his Lord and with full specialty asks him for many things. This feeling eventually gives rise to the clarity of spirituality, peace of mind, and self-security. At that moment man feels his calmness and mind as if finding his rest time.

Just like the results of the study above, when we perform prayers we will get a sense of comfort and tranquility. That's what makes our mental health good.

Shalat according to 'Arabic: prayer. According to the term syara' is worship that is done to make devotion and humility to Allah SWT. Establishing Salat is to eat the fish regularly, with the fire of the 
Volume I Tahun 2021

November 2021
E-ISSN: 2808-5361

http://e-journal.fkmumj.ac.id/
Proceeding The First Muhammadiyah InternasionalPublic Health and Medicine Conference

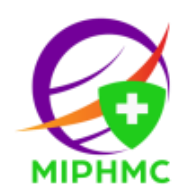

conditions, the pillars and the courtesy, either born or the inner, such as khusu', pay attention to what is read and so on.

Prayer is essentially an absolute necessity to manifest as a whole, the need of the human mind and soul, as it is the need to realize the society that is expected by humans as a whole. Prayer is needed by the mind and mind of man because it is a reflection of the relationship with Allah SWT.

In Surah Al-Baqoroh verse 153 which means "O you who believe, make patience and pray as your helper, verily Allah and those who are patient. ""

Berarti here patiently and prayer becomes the wisest and true way for a Muslim to deal with the problems and trials that befall him so that anxiety does not become prolonged stress.

In the letter Thaha verse 14 reads "Verily I am Allah, there is no God (right) but for me, so worship me and pray to remember me"

Explain that it is to pray for me, when you have established it, then you remember me. Explicitly, the verse conveys a set of conditions-answer. Therefore, prayer as a medium to remember is the best way that God provides for servants.

With prayer, man can achieve a degree of faith crowned with tranquility. These people will be different from those who do not pray. Therefore Allah (SWT) excludes them with the instability of the soul. Allah (SWT) says in surah Al-Ma'arij verses 19-23 which reads"Verily man is made miserly again when he is afflicted with the trouble he complains, and when he gets good he is very miserly, except those who do prayer, for whom they keep praying."

In this case, the person who performs the prayer has a stable and calm soul. There is no difference between the condition of adequacy of wealth with no treasure. Poverty is not a different face than wealth. The main capital that makes life balanced is the increase in the spiritual dimension of prayer.

\section{CONCLUSIONS}

Mental health in human life is a very important issue because it concerns the quality and happiness of humans. Without good health, people will not be able to get happiness and high quality of human resources. That is because what can guarantee human happiness is the psyche, health, and religiousness that humans have. These three factors are very much in line with achieving the happiness of human life in the world and the hereafter because the happiness that must be achieved is not only happiness in the world but also the happiness of the future.

Based on this study, researchers prove that individuals who always do prayer can overcome the problems of life that are being experienced, so they tend to have good mental health. The implementation 


$$
\begin{gathered}
\text { E-ISSN: } 2808-5361 \\
\text { http://e-journal.fkmumj.ac.id/ }
\end{gathered}
$$

Proceeding The First Muhammadiyah InternasionalPublic Health and Medicine

Conference

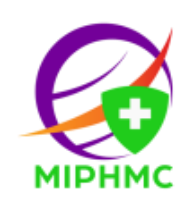

of worship in the context of Islam such as the implementation of prayers, remembrance, reading the Qur'an, and other worship, can be a way to get mental health.

The expects for researchers to then be able to look for research subjects that are more representative in terms of numbers, conditions, and so forth. So that the results of the study are more datarich. Furthermore, it is expected to use quantitative and qualitative combination research (mix method). This research only uses literature research, so to determine relationships or influences less can be possible. Therefore, it is advisable to use quantitative research.

\section{REFERENCES}

Firdaus (2016) 'SPIRITUALITY OF WORSHIP AS A PATH TO TRUE HEALTH', (1).

Ministry of Health (2018) 'RISKEDAS 2018'.

Lubis, L. T. et al. (2019) 'Improvement of the mental health of children and adolescents through Islamic worship', 16(2), pp. 120-129.

Ma'rufah, Y. (2015) 'BENEFITS OF PRAYER TO MENTAL HEALTH IN THE QUR'AN'.

Reza, I. F. (2015) 'EFFECTIVENESS OF THE IMPLEMENTATION OF WORSHIP to ACHIEVE MENTAL HEALTH', 1(1), pp. 105-115.

Suparman, D. (2015) 'Learning prayer in psychic and medical perspective', IX(2). 
Volume I Tahun 2021

November 2021
E-ISSN: 2808-5361

http://e-journal.fkmumj.ac.id/
Proceeding The First Muhammadiyah Internasional-

Public Health and Medicine Conference 